\title{
Phonological Constraints on the Utterance of L2 Clusters by Saudi ESL Learners
}

\author{
Abdullah N. Alotaibi \\ Department of English \\ Collage of Science and Humanities in Rumaah \\ Majmaah University, AL-Majmaah Saudi Arabia \\ Corresponding Author: an.otaibi@mu.edu.sa
}

Received: 9/21/2021

Accepted: $12 / 2 / 2021$

Published:12/27/2021

\begin{abstract}
:
The field of L2 phonology did not receive much research compared to the other linguistic domains. To add to the field and expand the current literature, the present paper's goal was to examine the impact of syllable structure differences between Arabic and English in uttering L2 English consonant clusters. The following research question was aimed to be answered: Do the differences between two languages' syllable structure cause production difficulties in the consonant cluster to Saudi Arabian learners of English? The subjects of this investigation were L2 English learners from Saudi with intermediate proficiency levels in English. Applying the descriptive correlational type of research model, the results showed that learners' production is mainly influenced by their native language-specific phonological features. The learners' production of targeted L2 consonant clusters seemed to mirror their underlying phonological system, and syllables structures were modified to match their native Arabic phonological system as a result of language transfer. These findings should be taken into account by $\mathrm{L} 2$ speech educators as such speech difficulty is anticipated.

Keywords: Consonant cluster, language interference, L2 phonology, L2 production, L2 perception, L2 syllable, Saudi Arabic
\end{abstract}

Cite as: Alotaibi, A. N. (2021). Phonological Constraints on the Utterance of L2 Clusters by Saudi ESL Learners. Arab World English Journal, 12 (4) 551-559.

DOI: https://dx.doi.org/10.24093/awej/vol12no4.36 


\section{Introduction}

In many cases the absent of intelligibility in L2 speech is due to misdealing with L2 phonological rules, especially in pronouncing marked sounds. This lead to failure in communication between the L2 speaker and the listener. The sufficient acquisition of L2 grammatical competence that includes L2 phonology is essential for L2 learner's fluency; thus, under the umbrella of communicative competence, phonology is counted as a core subcategory (Brown, 2007; Morley, 1991). Educators in the field of L2 need to emphasis more on speech issues. The L1 phonological system has always been hard to limit its patterns in L2 learner's speech, which constantly lead to have nonnative accent-like (Alotaibi, 2013; Alotaibi, 2018; Hameyer \& Grosse, 1976; Richards \& Schmidt, 2010).

The effect of an L1 phonological system can often be noticed in the production of an L2 consonant cluster, which is a set of consonant sounds that occur at the end, or the beginning of a syllable (Ladefoged \& Johnson, 1993). The difficulties in producing these clusters happen when L2 learners try to utter sounds according to the L2 phonological system. This is due to the fact that syllables and consonant clusters vary cross-linguistically from one language to another (Celce-Murcia, Brinton, Goodwin \& Griner, 2010; Jabbari \& Samvachi, 2011).

Taking this into account, the present study starts with reviewing some studies related to the literature, along with providing elaboration on phonological structure, centered on the syllable. Specifically, introduce syllable structure in targeted languages of this study, Arabic and English. Furthermore, it presents an essential hypothesis in the field named Contrastive Analysis that is used as a theoretical framework through which the data is interpreted; the hypothesis was proposed by Lado (1957).

\section{Literature Review Similar related studies}

One of the notable studies that inspected the utterance of clusters in English by L2 learners was Jabbari and Samavarchi (2011). They looked at the difficulties encountered by the L2 learners in pronouncing the L2 English consonant cluster. The subject, Persian native speakers, had to do a production task, which involved listening to the targeted clusters in words, each word was repeated twice, and the subject had to repeat the words back. The production of each one of the subjects was recorded and later analyzed acoustically.

The acoustic analysis showed that there were phonological changes in subjects' production for L2 consonant clusters, which seemed influenced by their L1 Persian phonological system, known as phonological interference. Specifically, they reconstruct the L2 syllable structure to look like and fit their L1 syllable structure by epenthesizing the onset cluster. This phonological modification leads to generate another extra new syllable, in their production for the word, instead of one syllable, because of having two consonant clusters.

The effect of such phonological interference is not only observed on the production but also on the perception of L2 sounds (Pallier, Bosch \& Sebastián-Gallés, 1997; SebastiánGallés, \& Soto-Faraco, 1999). Kabak and Idsard (2007) examined L2 English consonant clusters perceptual difficulties encountered by L1 Korean subjects. The researcher tried to spot the light on the cause of perceptual epenthesis; whether it was due to resections on 
phonological sequences that was influenced by the listeners' L1 phonological system in receiving L2 consonant cluster or no. The outcomes of their research illustrate the enormous role of subjects' native phonological system, that acted as a filter in perceiving targeted consonant clusters according to L1 Korean syllable structure. There was more of implementing epenthesis on the perceived cluster rather than neutralization or any other phonological changes such as nasalization or lateralization.

In a similar vein, Chang (2004) examined the nature of difficulties encountered by L2 Chinese learners during the phonological processing of the English consonant clusters. The types of errors found traced back to subjects' L1 Chinese phonological system, which allows just one single consonant in its onset within the syllable structure, unlike English that allows one, two, and three consonants in its onset. This divergence between the two languages syllable structure led to phonological interference that caused the omission of the sound cluster in the onset, and epenthesis to break up the cluster. Besides syllable complexity, speech rate was also found to have a role in increasing the difficulties in perceiving consonant clusters.

Byrd and Tan (1996) looked at the acoustic length of the consonants, phonemic boundaries, and latency effect in phonological processing. They found that it is also a factor that could hinder the perception of L2 clusters, causing overlap or displacement of consonants, endorsed by the divergence between the L1 and L2 syllable structure. It is worth noticing here that consonant cluster is classified as marked, meaning that it is rare to be found in world languages (Greenberg, 2005; Schreier, 2005). A term refers to linguistics features that are not common and not shared among learners' first language and second language as defined by the Markedness Differential Hypothesis (Eckman, 1977).

In Arabic language, initial consonant clusters are considered to be marked phonological feature, because it does not exist in Arabic phonological system (Al-Ani, 1970). Therefore, Arabic ESL learners would encounter difficulties in producing L2 English words that have word-initial consonant clusters (Jabbari \& Fazlinezhad, 2011). "Second language (L2) learners of English are more likely to encounter obstacles, when it comes to communicating freely with English native speakers. In fact, this difficulty is somewhat anticipated, especially when the two languages being compared come from different backgrounds" (Al-Yami \& Al-Athwary, 2021, p. 1237). Similar to earlier mentioned studies, Arabic ESL learners may alternate L2 phonological feature, syllable structure, through epenthesis or omission, to tailor it to look like their L1 Arabic phonological features.

\section{Syllable structure cross-linguistically}

According to Nathan (2008), In any world language, a syllable under the phonological domain can be deconstructed into a vowel, which is the head of a syllable and named as "Rhyme" or "Nucleus" respectively. Consonant represents the other two parts, "Onset" at the beginning of the nucleus or "Coda" at the end of the syllable, see Figure 1. However, it is possible that a syllable can have no coda, but it must have a nucleus because there are phonological rules that need to be followed in constructing a syllable. Yet, this phonological rule is language-specific and varies across-world languages (O'Grady, Katamba, Archibald, 2011). For instance, the Arabic phonological rule does not allow consonant clusters in the onset (Watson, 2002)., while the English language does allow (Treiman, 1989). 


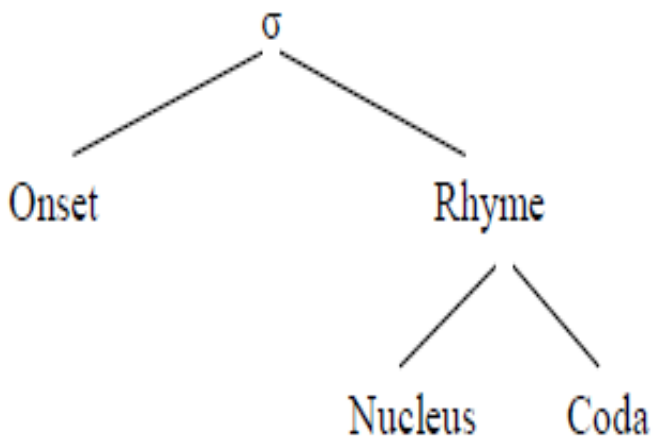

Figure 1. Syllable hierarchical deconstruction

\section{Arabic syllable structure}

According to Watson (2002), Arabic syllable structure has five types of syllables. See Table1. These types of syllables are considered to be unmarked syllables in world languages. The lowest necessary construction of the Arabic syllable is a CV, and the highest component is CVCC (Al-Ani, 1970). Arabic consonant clusters exist only in the coda, and there are no onset consonant clusters. The highest number of clusters is two, as can be viewed in Table 1.

Table 1. Arabic syllable structure

\begin{tabular}{ccc}
\hline Syllable Type & Arabic example & Gloss \\
CV & {$[$ la] } & no \\
CVV & {$[\mathrm{fei}]$} & in \\
CVC & {$[$ qam $]$} & Stand up \\
CVVC & {$[$ saam] } & fasted \\
CVCC & {$[$ sabt] } & sturday \\
\hline
\end{tabular}

\section{English syllable structure}

In the English language, the syllable structure has more variety than the Arabic language. A common syllable between the two languages would be CV, CVC, and CVCC. Yet, there are more fourteen syllables in English than in Arabic, see Table 2. Unlike Arabic, English allows both onset and coda consonant clusters. Also, the consonant clusters in English can consist of two, three, and four consonants (Treiman, 1989). Based on this, and according to the CAH Hypothesis, one could predict that Arabic learners of English could encounter difficulties in both, producing and perceiving L2 English syllables.

Table 2. L2 targeted syllables

$\begin{array}{cc}\text { Syllable Type } & \text { English example } \\ \text { V } & \text { eye } \\ \text { VC } & \text { am } \\ \text { VCC } & \text { ask } \\ \text { VCCC } & \text { amps } \\ \text { CV } & \text { knee } \\ \text { CVC } & \text { sick } \\ \text { CVCC } & \text { best }\end{array}$




\begin{tabular}{cc}
\hline CCV & blue \\
CCVC & sleep \\
CCVCC & stink \\
CCVCCC & prints \\
CCVCCCC & bursts \\
CCCV & scree \\
CCCVC & straight \\
CCCVCC & sprint \\
CCCVCCC & sprints \\
CCCVCCCC & splints \\
\hline
\end{tabular}

\section{The Contrastive Analysis Hypothesis (CAH)}

In this study, the Contrastive Analysis Hypothesis serves as the theoretical framework, based on which the outcomes are discussed. The theory was introduced by Lado (1975) and simply state that by considering L1 linguistics characteristics and specifics in comparison to L2, points of difficulties for L2 learner could be predicted. That is, the shared phonological characteristics between L1 and L2 are transferable and easy to produce, while those that are different could be difficult to acquire. The theory helps to a great extent to identify the point of difficulties and errors during the learning process in the L2 language. It would help to explain the production difficulties in producing L2 English clusters by Arabic learners. The research agenda at the core of this investigation is translated into the following research question:

Do the differences between two languages' syllable structure cause production difficulties in the consonant cluster to Saudi Arabian learners of English?

\section{Methodology participants}

The subjects were 12 Saudi Arabic ESL, with an age range between 24 and 29 and a mean age of 26. They were chosen among ESL learners at US college and had a length of stay for at least 8 months. The recruiting process was conducted through a word-of-mouth announcement given at social academic events. The self-reported proficiency level, based on TOEFL scores, all subjects were in the intermediate level.

\section{Research Instrument}

The implemented instrument in data collection included reading a list of six sentences from a handout paper. Each of the sentences included two to three targeted consonant clusters in English words, see Table 3. The overall number of consonant clusters was fourteen, and the subject utterance for these clusters was recorded.

Table 3. Sentences that were given to the subjects to read out from the handout.

A. The boy with the red surfboard chased the man who made the structure with a sponge.

B. My strategy was approved, and no one stole the magical plant.

C. I asked if the hen eats tree leaves and ants.

D. In spring the streets are beautiful.

E. The school truck door was a slab.

F. the desk starts to break. 
Arab World English Journal (AWEJ) Volume 12. Number 4. December 2021

Phonological Constraints on the Utterance of L2 Clusters

Alotaibi

\section{Research Procedure}

Since there was a recording for the targeted clusters, each subject was taped separately in a calm lab-room using the speech analyzer program. The subject had to familiarize themselves with sentences for four minutes. Then the subject was required to read each sentence loudly three times. Later, the elicited data was analyzed through spectrograms via speech analyzer software and transcribed using IPA symbols.

\section{Results and discussion}

The current study was interested in the utterance of L2 consonant clusters by Saud Arabian ESL learners. For this purpose, it aimed to provide an in-depth account of how syllable structure differences between the two languages, Arabic and English, could affect the production of English consonant clusters by Saudi Arabian ESL learners. The subjects' utterances were transcribed phonetically as can be viewed below in Table 4.

Table 4. Subjects' utterance for targeted word, each subject was coded as " $S$ " followed by his data number.

S1. /serfbo:red/, /straktfər/, /spandz/, /stratədzI/, /a'pru:ved/, /satul/, /palant/, /ask/, /i:təs/, /tri:/,/li:vz/,/ænts/,/espirıy/,/estri:t/,/esku:1/,/truk/,/silæb/,/disik/,/esta:rt/,/birek/.

S2. /serfbo:rd/, /estrakitfər/, /espandz/, /estratədzi/, /a'pru:ved/, /stul/, /plant/, /ask/, /i:təs/, /tri:/,/li:vəz/,/ænts/,/espirıy/,/stri:t/,/esku:1/,/truk/,/slæb/,/disik/,/esta:rt/,/birek/.

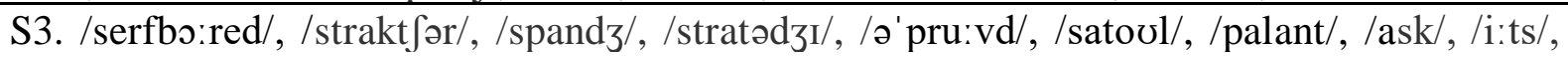
/teri:/,/li:vz/,/ænts/,/espirin/,/estri:t/,/esku:1/,/truk/,/silæb/,/disik/,/esta:rt/,/birek/.

S4. /serfbo:red/, /estrakitfər/, /spandz/, /stratədzi/, /ə'pru:ved/, /stul/, /plant/, /ask/, /i:təs//teri:/,/li:vz/,/ænts/,/espirı//,/estri:t/,/sku:1/,/truk/,/silæb/,/disik/,/esta:rt/,/birek/.

S5. /serfbo:rd/,/estrakit_ər/,/spandz/,/stratədzI/,/o'pru:ved/,/satul/,/plant/,/ask/,/i:ts/,/tri:/, /li:vz/,/æntes/,/espirıy/,/estri:t/,/sku:1/,/toruk/,/silæb/,/disk/,/esta:rt/,/birek/.

S6. /serfbo:rd/, /estrakitfər/, /espandz/, /stratədzi/, /a'pru:ved/, /satul/, /palant/, /ask/, /i:ts/, /tri:/,/li:vəz/,/æntes/,/espirin/,/estri:t/,/sku:1/,/truk/,/silæb/,/disk/,/esta:rt/,/birek/.

S7. /serfbo:rd/,/estrakit_ər/,/espandz/,/stratədzi/,/o' pru:vd/,/stul/,/plant/,/ask/,/i:təs/,/tri:/, /li:vz/,/æntes/,/espirı//,/estri:t/,/esku:1/,/turuk/,/silæb/,/disik/,/sta:rt/,/birek/.

S8. /serfbo:rd/,/estrakitfər/,/spandz/,/estratədzı/,/ə' pru:vd/,/stul/,/palant/,/ask/,/i:ts//teri:/, /li:vəz/,/ænts/,/espirı/,//estri:t/,/sku:1/,/turuk/,/silæb/,/disik/,/esta:rt/,/birek/.

S9. /serfbo:red/,/estrakit_ər/,/espandz/,/estratədzI/,/ə'pru:ved/,/stul/,/palant/,/asik/,/i:təs/, /teri:/,/li:vəz/,/æntes/,/spirı/,,/estri:t/,/esku:1/,/turuk/,/slæb/,/disk/,/esta:rt/,/birek/.

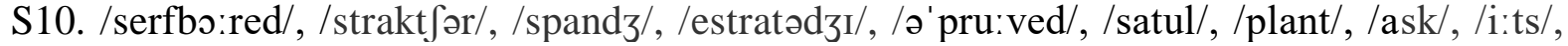
/tri:/,/li:vəz/,/ænts/,/espirı//,/estri:t/,/esku:1/,/turuk/,/silæb/,/disk/,/sta:rt/,/birek/.

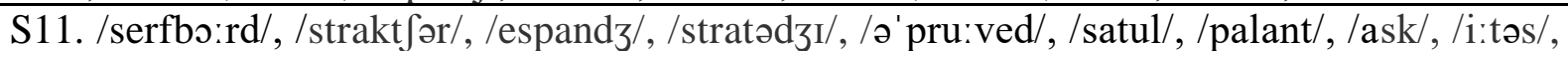
/tri:/,/li:vəz/,/ænts/,/espirı//,/estri:t/,/esku:1/,/turuk/,/silæb/,/disik/,/sta:rt/,/birek/.

S12. /serfbo:rd/,/estrakit_ər/,/spandz/,/stratədzI/,/a' pru:ved/,/stul/,/plant/,/ask/,/i:ts/,/tri:/, /li:vəz/,/ænts/,/espirıy/,/estri:t/,/sku:1/,/truk/,/slæb/,/disik/,/esta:rt/,/birek/.

The targeted words were later analyzed according to error frequency in each word. Phonological epenthesis in the subjects' production was counted as an error; see Table 5 below. 
Table 5. Error frequency per word.

\begin{tabular}{|c|c|c|c|}
\hline Word & Epenthesis & Word & Epenthesis \\
\hline s3:rfbo:rd & 5 & o'pru:vd & 9 \\
\hline $\operatorname{str} \Lambda \mathrm{kt} \int \partial \mathrm{r}$ & 8 & stool & 6 \\
\hline $\operatorname{sp} \wedge$ nd 3 & 5 & plænt & 6 \\
\hline strætədzI & 4 & a:sk & 1 \\
\hline i:ts & 6 & ænt & 4 \\
\hline tri: & 3 & sprin & 12 \\
\hline li:vz & 7 & stri:t & 11 \\
\hline sku:1 & 7 & desk & 8 \\
\hline $\operatorname{tr} \Lambda \mathrm{k}$ & 6 & sta:rt & 9 \\
\hline slæb & 9 & breık & 12 \\
\hline
\end{tabular}

The results show quite interesting findings regarding the production of L2 English clusters. It provides evidence regarding the role of the L1 phonological system, full transfer, on the subjects' production. The elicited data implies that all types of L2 consonant clusters in targeted syllable structures, VC, VCC, CCV, CVCC, CCVC, CCVCC, and CCCV are treated the same. What happened here is that subjects may have treated the clusters as high on the scale of markedness (Greenberg, 2005; Schreier, 2005). That is, a cluster that is rare or does not exist in L1 Arabic, were problematic for them to utter, which is similar to the pattern seen before in Korean L2 learners (Kabak \& Idsard, 2007). The subjects' production errors here could be attributed to the sequence of consonants in Arabic clusters, which is language-specific (Al-Ani, 1970).

Definitely, the observed errors found on the subjects' production were not erratic, but rather systematic caused by L1 Arabic. Consonant sonority profile within the cluster of L2 could constrain a challenge for L2 learners. Although the subjects were all intermediate level learners, their L2 acquired phonological system is still under development and ongoing process, which is vulnerable to interlanguage phonology as illustrated by Lado (1975), through his Contrastive Analysis Hypothesis. As seen in the literature, the subject demonstrator pattern is similar to the ones observed in Chang's (2004) study for Chinese learners acquiring English as L2.

In addition to the difference between L1 and L2 phonological systems, words familiarity in the used stimuli could be a count as a factor that has a role in increasing the error rate on the subjects' performance. Looking into the Arabic phonological system, one could postulate that the subjects should be able to produce the coda clusters easily in L2 English. Especially that some of the production errors did not have an effect trace of the phonological system of L1 neither L2. Another factor is input quality that could affect the phonological skills of learners (Alotaibi, 2018), having sufficient and high quality of L2 phonological input could help the learners to acquire L2 native-like speech (Nogoud, 2020).

\section{Conclusion}

The analysis of this paper has illustrated the impact of L1 phonological system-specific in the production of targeted L2 consonant clusters. The data showed evidence that having a cluster in the native language does not mean the case that learners would be successful in producing consonant clusters in L2. In this paper, it was clear that phonological transfer played an enormous role that can be observed under the scope of the Contrastive Analysis Hypothesis 
by comparing the two languages' phonological systems. Last but not least, further research on the perceptional level as in production level is needed to have a better understanding of the learner's underline phonological processing. Also, considering individual differences, specifically in the amount of language use among subjects, along with some other extralinguistic factors such as age and social background, would help to understand their potential effect on the subjects' speech.

\section{About the Author:}

Dr. Abdullah Nijr Alotaibi is an assistant professor of Applied linguistics at Majmaah University. He received his doctoral degree from Indiana University, USA. His research interests are in the area of second language learning, developmental speech perception, and Phonetic cues in second language perception and production. ORCiD ID: https://orcid.org/0000-0002-15979480

\section{Reference}

Al-Ani, S. (1970). Arabic Phonology: an acoustical and phonological investigation. The Hague, Paris: Mouton publisher.

Alotaibi, A. (2013). Pronunciation Problems in the production of the voiced labiodental fricative $/ v /$ by Saudi speakers of English. (Unpublished master's thesis). Southern Illinois University Carbondale, Carbondale, Illinois, USA.

Alotaibi, A. (2018). The role of native language dialect on the perception of L2 English vowels. (Unpublished doctoral dissertation). Indiana University at Bloomington.

Al-Yami, E. M. \& Al-Athwary, A. H. (2021). Phonological analysis of errors in the consonant cluster system encountered by Saudi EFL learners. Theory and Practice in Language Studies, 11 (10), 1237-1248.

Brown, H. D. (2007). Principles of language learning and teaching (5th ed.). NewYork: Pearson Press.

Celce-Murcia, M., Brinton, D.M., Goodwin, J. M., \& Griner, B. (2010). Teaching pronunciation: reference for teachers of English to speakers of other languages (2nd ed.). New York: Cambridge University Press.

Eckman, F. R. (1977). Markedness and the contrastive analysis hypothesis. Language Learning: Journal of Linguistic Studies Research, 27(2), 315-30.

Chang, F. C. (2004). Chinese-speaking EFL learners' performances of processing English consonant clusters: International Conference on English Instruction and Assessment . National Chiayi University.

Greenberg, J.H. (2005). Universals of language (2nd ed.). Cambridge: MIT Press.

Hameyer, K., \& Grosse, C. (1976). The Influence of dialect and reading on second language learning. New York: ERIC Clearinghouse on Urban Education. (ERIC No. ED132844)

Jabbari, A. A. \& Fazlinezhad, A. (2011). Acquisition of English syllable structure as a foreign language by Iranian Farsi and Arabic speakers. Iranian EFL Journal, 7 (3), 227-242.

Jabbari, A. A., \& Samavarchi, L. (2011). Persian learners' syllabification of English consonant clusters. International Journal of English Linguistics, 1, 236-246.

Kabak, B., \& Idsardi, W. J. (2007). Perceptual distortions in the adaptation of English consonant clusters: Syllable structure or consonantal contact constraints? Language and Speech, 50 (1), 23-52. http://dx.doi.org/10.1177/00238309070500010201 
Ladefoged, P., \& Johnson, K. (1993). A course in phonetics. Fort Worth: Harcourt Brace Jovanovich College.

Lado, R. (1957). Linguistics across cultures: Applied linguistics for language teachers. Cambridge University Press

Morely, J. (1991). The pronunciation component in teaching English to speakers of other languages. TESOL Quarterly, 25(3), 581-520.

Nathan, Geoffrey S. (2008). Phonology: A cognitive grammar introduction. Amsterdam Philadelphia: John Benjamins Publishing Company.

Nogoud, J. A. (2020). Phonotactic Cruciality of English Initial and Final Consonant Clusters' Pronunciation on Sudanese EFL Undergraduates. European academic research, 8 (3), 2131-1251.

O'Grady, W., Katamba, F., \& Archibald, J. (2011). Contemporary linguistics: An introduction (2nd ed.). London: Longman.

Pallier, C., Bosch, L., \& Sebastián-Gallés, N. (1997). A limit on behavioral plasticity in speech perception. Cognition, 64 (3), B9-B17.

Schreier, D. (2005). Corpus-based evidence of historical change in English phonotactics. International Journal of English Studies, 5 (1), 77-99.

Sebastián-Gallés, N. \& Soto-Faraco, S. (1999). On-line processing of native and non-native phonemic contrasts in early bilinguals. Cognition 72, 111-123.

Treiman, R. (1989). The internal structure of the syllable. In Greg N. Carlson \& Michael K. Tanenhaus (eds.), Linguistic structure in Language Processing, 27-52. Dordrecht, Boston, London: Kluwer Academic Publishers.

Richards, J. C., \& Schmidt, R. (2010). Longman dictionary of language teaching and applied linguistics (4th ed.). London: Longman.

Watson, J. C. E. (2002). The Phonology and Morphology of Arabic. New York: Oxford University Press. 